\title{
A Nyírség gyertyános-tölgyesei (Convallario-Carpinetum Kevey 2008)
}

\author{
KEVEY Balázs ${ }^{1}$, PAPP László ${ }^{2}$ é LENDVAI Gábor ${ }^{3}$ \\ ${ }^{1}$ Pécsi Tudományegyetem, Ökológiai Tanszék, \\ 7624 Pécs, Ifjúság u. 6.; keveyb@ttk.pte.hu \\ ${ }^{2}$ Debreceni Egyetemi Botanikus kert, \\ 4032 Debrecen, Egyetem tér 1.; papp.laszlo@gf.unideb.hu \\ ${ }^{3} 7000$ Sárbogárd, Ady E. u. 162.; gaborlendvai@hotmail.com \\ Elfogadva: 2017. március 18.
}

\begin{abstract}
Kulcsszavak: cluster-analízis, Magyar Alföld, növénycönológia, ordináció, természetvédelmi terület.

Összefoglalás: Jelen tanulmány Magyarország keleti részén, a Nyírség gyertyános-tölgyeseinek társulási viszonyait mutatja be 50 cönológiai felvétel alapján. Mivel a gyertyános-tölgyes zónán kívül fordulnak elő, a tölgyes zónán belüli megjelenésük extrazonálisnak tekinthető, amely a talajvíz által mérsékelten befolyásolt üde mikroklímának köszönhető. Állományaikban feltűnőek egyes szubmontán elemek, amelyek az Alföldön általában ritkák. Különösen a Fagetalia elemek gyakorisága jellemzö: Actaea spicata, Allium ursinum, Anemone ranunculoides, Arum orientale, Asarum europaeum, Athyrium filix-femina, Cardamine bulbifera, Carex pilosa, Carpinus betulus, Cerasus avium, Corydalis cava, Corydalis solida, Dryopteris filix-mas, Epipactis helleborine agg., Euphorbia amygdaloides, Galeobdolon luteum, Galium odoratum, Hedera helix, Isopyrum thalictroides, Lathraea squamaria, Lathyrus vernus, Lilium martagon, Majanthemum bifolium, Mercurialis perennis, Milium effusum, Polygonatum multiflorum, Pulmonaria officinalis, Ranunculus cassubicus, Salvia glutinosa, Sanicula europaea, Scilla vindobonensis, Stachys sylvatica, Stellaria holostea, Ulmus glabra, Vinca minor stb. E növények főleg a Nyírség keleti részén fordulnak elö, $s$ valószínűleg a hűvösebb, csapadékosabb és kiegyenlítettebb klímájú Bükk I. kor (i.e. 2500-tól i.e. 800-ig) maradványfajai. Az asszociáció nehezen választható el a tölgy-kőris-szil ligeterdőktől (Fraxino pannonicae-Ulmetum). Ennek oka az állományok fragmentációja, izolációja és a helyenkénti eltérő tájhasználat (lecsapolások, erdőgazdálkodás).
\end{abstract}

\section{Bevezetés}

A Nyírség tölgy-kőris-szil ligeterdeiről először Soó (1937) közölt öt felvétel alapján egy listát, majd később (Soó 1943) Baktalórántházáról ismertetett egyetlen teljes felvételt. Bátorliget mellől Soó (1953) nem említ gyertyános-tölgyeseket, csupán a tölgy-kőris-szil ligetek gyertyános-tölgyesek felé mutató típusairól (Allium ursinum, Asarum europaeum, Galium odoratum) tesz említést. Legutóbb PAPP et al. (1986) közölt cönológiai adatokat a Bátorliget melletti Fényi-erdőből, s írják, hogy „helyenként a Carpinus betulus is elöfordul a ligeterdő fafajai mellett”, de gyertyános-tölgyesről, mint asszociációról e tanulmányban nem olvashatunk. 
A Nyírség homoki gyertyános-tölgyeseiből 1982 és 2005 között 61 cönológiai felvételt készítettünk. Mivel e gyertyános-tölgyesekről mindeddig nem jelent meg részletes tanulmány, érdemesnek láttuk, hogy 50 felvétel alapján jellemezzük ezt az eltűnőben levő erdőtársulást.

\section{Anyag és módszer}

\section{A kutatási terület jellemzése}

A Nyírség Magyarország keleti részének homokvidéke, amely Nyírségense néven önálló flórajárásnak tekinthető (vö. Soó 1960). A homok alapkőzet felső rétege barna erdőtalajjá fejlődött. Gyertyános-tölgyesek olyan helyeken jöttek létre, ahol vízgazdálkodási szempontból a talaj megfelelően üde, $s$ hűvös és párás mikroklímát biztosít a lágy szárú növényzet számára. A természetes vegetációból azonban kevés erdő érte meg a jelenkort, így a gyertyános-tölgyesek is erősen megfogyatkozhattak. E természetes és még természetszerűnek mondható gyertyános-tölgyes erdőkben végeztük felméréseinket. A felvételezett állományok 117-150 m tengerszint feletti magasság mellett találhatók. Sík vidék lévén az égtáji kitettség és a lejtőszög e társulás kialakulásában nem játszik szerepet.

\section{Alkalmazott módszerek}

A cönológiai felvételeket a Zürich-Montpellier növénycönológiai iskola (BECKING 1957; BRAUN-BLANQUET 1964) hagyományos kvadrát-módszerével készítettük. A felvételek táblázatos összeállítását, valamint a karakterfajok csoportrészesedését és csoporttömegét az „NS” számítógépes programcsomag (Kevey és HirmanN 2002) segítségével végeztük. A felvételkészítésnél a szintek magasságának és borításának, valamint az átlagos törzsátmérő meghatározása becsléssel történt. A hagyományos statisztikai számítások módszerét KEVEY (2008) korábban részletesen közölte. Az asszociációk összehasonlításánál a SynTax 2000 programcsomag (PODANI 2001) segítségével bináris cluster-analízist (hasonlósági index: Baroni-Urbani-Buser; fúziós algoritmus: összetett lánc) és ugyancsak bináris ordinációt végeztünk (hasonlósági inedex: Baroni-UrbaniBuser; fúziós algoritmus: főkoordináta-analísis).

Mivel a terepmunka során láttuk, s továbbá az eredményeknél is kiderült, hogy a gyertyános-tölgyesek (Convallario-Carpinetum) nem különíthetők el egyértelműen a velük rokon, ill. a velük gyakran érintkező tölgy-kőris-szil ligeterdőktől (Fraxino pannonicae-Ulmetum), a felvételek szelektálásával szűkített analízist is végeztünk. Ennek megfelelően a nyírségi felvételi anyagunkból kiválasztottunk két olyan erdőt, amelyekben mindkét asszociációból megfelelő számú felvételünk volt. Így a bátorligeti Fényi-erdőből és a mérki Vadaskerti-erdőből 
10-10 tölgy-kőris-szil ligeterdő (Fraxino pannonicae-Ulmetum) és 10-10 gyertyános-tölgyes (Convallario-Carpinetum) felvételt használtunk fel további elemzésre. E felvételi anyagokon szintén meghatároztuk a karakterfajok arányát és elvégeztük a fenti sokváltozós analíziseket.

A fajok esetében Király (2009), a társulásoknál pedig az újabb hazai nómenklatúrát (BORHIDI és KEVEY 1996; KEVEY 2008; BORHIDI et al. 2012) követjük. A társulástani és a karakterfaj-statisztikai táblázatok felépítése az újabb eredményekkel (OBERDORFER 1992; MuCina et al. 1993; KEVEY 2008; BORHIDI et al. 2012) módosított Soó (1980) féle cönológiai rendszerre épül. A növények cönoszisztematikai besorolásánál is elsősorban Soó (1964, 1966, 1968, 1970, 1973, 1980) Synopsis-ára támaszkodtunk, de figyelembe vettük az újabb kutatási eredményeket is (vö. BorHidi 1993, 1995; HoRvÁtH et al. 1995; KeVEY 2008).

\section{Eredmények}

\section{Termőhelyi viszonyok, zonalitás}

BORHIDI (1961) klímazonális térképe szerint a Nyírség a zárt tölgyes zónába tartozik, amelyet e tájon a gyöngyvirágos-tölgyes (Convallario-Quercetum roboris) képvisel. A homoktáblákat átszelő patakok mentén és olyan helyeken, ahol a talajvízszint viszonylag közel van a felszínhez, e gyöngyvirágos-tölgyeseket azonális tölgy-kőris-szil ligetek (Fraxino pannonicae-Ulmetum), a kevésbé nedves helyeken pedig gyertyános-tölgyesek (Convallario-Carpinetum) váltják fel. A három asszociáció ma is több helyen érintkezik, s közöttük szukcessziós kapcsolat áll fenn (KEVEY 2008). Mivel e homoki gyertyános-tölgyesek a klímazónájukon kívül fordulnak elő, a tölgyes zónán belüli megjelenésük extrazonálisnak tekinthető, amely a talajvíz által kissé befolyásolt üde mikroklímának köszönhető.

\section{Fiziognómia}

A vizsgált gyertyános-tölgyesek az állomány korától függően 20-32 m magasak, felső lombkoronaszintjük közepesen, vagy jól záródó (50-90\%). Állandó fajai (K: IV-V) a Carpinus betulus és a Quercus robur. Nagyobb tömegben (A-D: 3-5) a Carpinus betulus és a Quercus robur mellett a Fraxinus angustifolia, a Populus $a l b a$, a Tilia cordata és a Tilia tomentosa is elöfordulhat. Az alsó lombkoronaszint igen változóan fejlett. Magassága 12-20 m, borítása pedig 10-70\%. Főleg alászorult fák alkotják. Állandó faja (K: IV-V) a Carpinus betulus mellett az Acer campestre. E két fafaj mellett nagyobb tömeget (A-D: 3-4) csak a Tilia cordata és a Tilia tomentosa ér el.

A cserjeszint ugyancsak változóan fejlett, amely elsősorban erdészeti beavatkozásokkal kapcsolatos. Magassága 1-5 m, borítása pedig 3-60\%. Állandó eleme- 
it (K: IV-V) főleg fiatal fák képezik: Acer campestre, Carpinus betulus, Crataegus monogyna, Ulmus minor. Nagyobb tömeget (A-D: 3-4) is föleg fiatal fák érnek el: Acer campestre, Acer tataricum, Carpinus betulus, Staphylea pinnata, Tilia tomentosa. Az alsó cserjeszint (újulat) borítása mindössze 1-20\%. Állandó fajai (K: IV-V) az alábbiak: Acer campestre, Carpinus betulus, Cerasus avium, Crataegus monogyna, Fraxinus angustifolia, Ligustrum vulgare, Quercus robur, Sambucus nigra, Ulmus minor. Nagyobb tömeget (A-D: 3-5) e szintben egyetlen faj sem ér el.

A gyepszint fejlett, borítása szintén szélsőséges értékeket mutat (5-100\%). Állandó elemei (K: IV-V) a következők: Alliaria petiolata, Brachypodium sylvaticum, Bromus ramosus, Chaerophyllum temulum, Circaea lutetiana, Convallaria majalis, Fallopia dumetorum, Galeopsis pubescens, Galium aparine, Geranium robertianum, Geum urbanum, Lapsana communis, Milium effusum, Moebringia trinervia, Polygonatum multiflorum, Ranunculus ficaria, Stachys sylvatica, Urtica dioica, Viola reichenbachiana. Fáciest (A-D: 3-5) az alábbi növények képeznek: Aegopodium podagraria, Allium ursinum, Cardamine bulbifera, Convallaria majalis, Corydalis cava, Galium odoratum, Ranunculus ficaria, Polygonatum latifolium, Ranunculus ficaria, Vinca minor, Viola suavis.

\section{Fajkombináció \\ Állandósági osztályok}

Az 50 cönológiai felvétel alapján a társulásban 15 konstans és 14 szubkonstans faj szerepel az alábbiak szerint: K V: Acer campestre, Alliaria petiolata, Brachypodium sylvaticum, Carpinus betulus, Circaea lutetiana, Crataegus monogyna, Euonymus europaea, Galium aparine, Geranium robertianum, Geum urbanum, Moehringia trinervia, Polygonatum multiflorum, Quercus robur, Ranunculus ficaria, Viola reichenbachiana. - K IV: Bromus ramosus, Cerasus avium, Chaerophyllum temulum, Convallaria majalis, Fallopia dumetorum, Fraxinus angustifolia, Galeopsis pubescens, Lapsana communis, Ligustrum vulgare, Milium effusum, Sambucus nigra, Stachys sylvatica, Ulmus minor, Urtica dioica. A felvételi anyagban ezen kívül 21 akcesszórikus (K III), 30 szubakcesszórikus (K II) és 118 akcidens (K I) faj is szerepel (vö. 1. ábra; E1-E2. táblázatok, elektronikus mellékletben). Az állandósági osztályok terén tehát a legkisebb fajszám a szubkonstans (K IV) és a konstans (K V) elemeknél van.

\section{Karakterfajok aránya}

A Nyírség gyertyános-tölgyesei viszonylag sok szubmontán elem számára nyújtanak menedéket. Ilyen Fagetalia jellegü fajok az alábbiak: K V: Carpinus betulus, Circaea lutetiana, Moehringia trinervia, Polygonatum multiflorum, Viola reichenbachiana. - K IV: Cerasus avium, Milium effusum, Stachys sylvatica. - K III: 


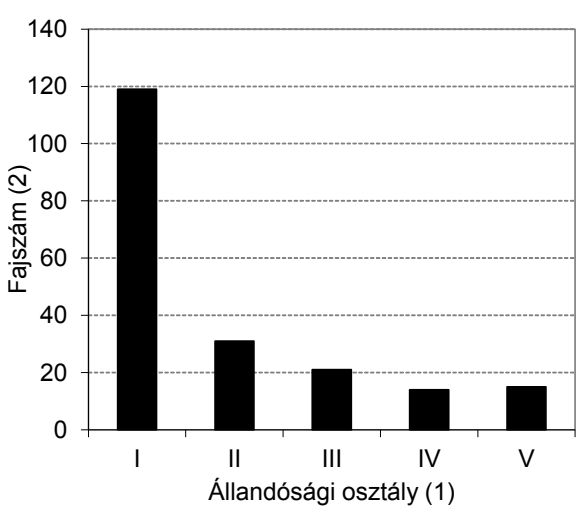

1. ábra. Állandósági osztályok eloszlása.

Fig. 1. Frequency of constancy categories. (1) Constancy catehory; (2) Number of species.

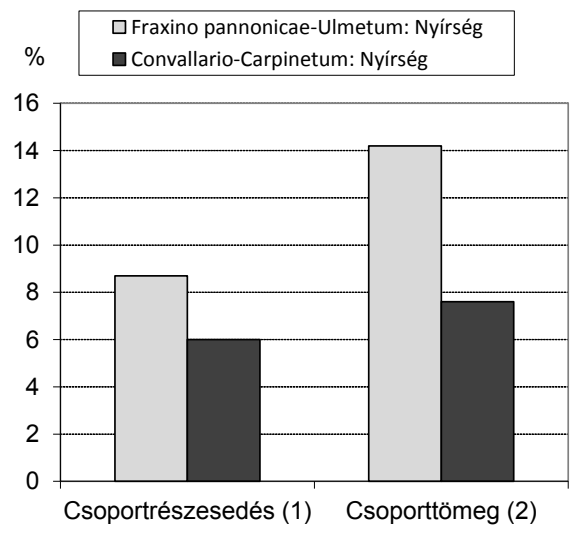

3. ábra. Fagetalia elemek aránya a bátorligeti Fényi-erdő tölgy-kőris-szil ligeteiben (Fraxino pannonicae-Ulmetum) és a baktalórántházi Baktai-erdő gyertyános-tölgyesében (ConvallarioCarpinetum).

Fig. 3. Relative frequencies of Fagetalia species in the oak-ash-elm (Fraxino pannonicae-Ulmetum) forest of Fényi-erdő, Bátorliget and in the oak-hornbeam (Convallario-Carpinetum) forest of Baktai-erdő, Baktalórántháza. (1) Relative frequency; (2) Relative frequency weighted with cover values.

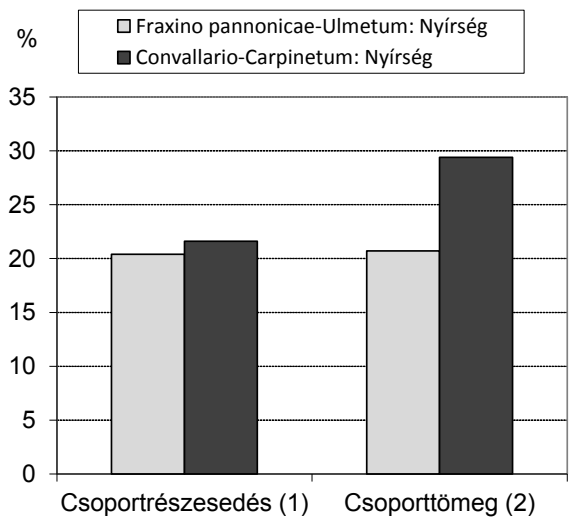

2. ábra. Fagetalia elemek aránya a Nyírség tölgy-kőris-szil ligeterdeiben (Fraxino pannonicae-Ulmetum) és gyertyános-tölgyeseiben (Convallario-Carpinetum).

Fig. 2. Relative frequencies of Fagetalia species in the oak-ash-elm (Fraxino pannonicae-Ulmetum) and oak-hornbeam (Convallario-Carpinetum) forests of Nyírség. (1) Relative frequency; (2) Relative frequency weighted with cover values. 
Cardamine bulbifera, Carex sylvatica, Dryopteris filix-mas, Galium odoratum, Hedera helix. - K II: Actaea spicata, Athyrium filix-femina, Corydalis cava, Epipactis helleborine (incl. E. tallósii), Lilium martagon, Listera ovata, Pulmonaria officinalis, Salvia glutinosa, Sanicula europaea. - K I: Acer platanoides, Acer pseudoplatanus, Aegopodium podagraria, Allium ursinum, Anemone ranunculoides, Arum orientale, Asarum europaeum, Cardamine impatiens, Carex pilosa, Chaerophyllum aromaticum, Corydalis solida, Epilobium montanum, Euphorbia amygdaloides, Galeobdolon luteum, Glechoma hirsuta, Isopyrum thalictroides, Latbraea squamaria, Lathyrus vernus, Majanthemum bifolium, Mercurialis perennis, Paris quadrifolia, Ranunculus cassubicus, Scilla vindobonensis, Stellaria holostea, Ulmus glabra, Vinca minor (E1. táblázat, elektronikus mellékletben). Arányuk kissé magasabb, mint a tölgy-kőris-szil ligetekben (Fraxino pannonicae-Ulmetum) (3. táblázat (elektronikus mellékletben), 2. ábra).

A gyertyános-tölgyesekben viszonylag jelentősek a keményfaligeti (Alnion incanae) elemek is (E1. táblázat, elektronikus mellékletben). Ilyen jellegü növények a következök: K IV: Fraxinus angustifolia. - K III: Elymus caninus, Viburnum opulus.

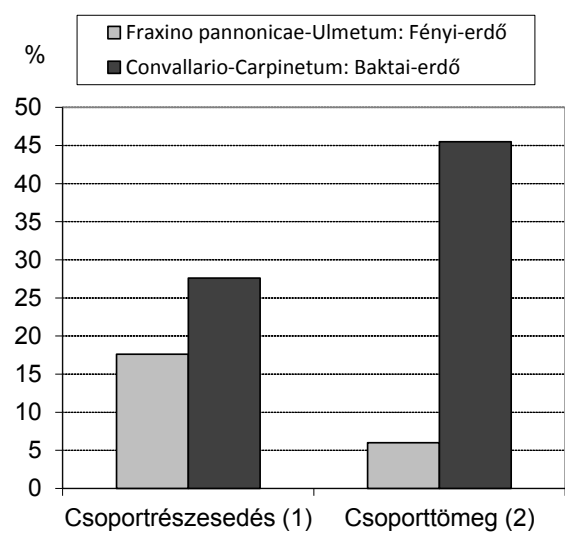

4. ábra. Alnion incanae elemek aránya a Nyírség tölgy-köris-szil ligeterdeiben (Fraxino pannonicae-Ulmetum) és gyertyános-tölgyeseiben (Convallario-Carpinetum).

Fig. 4. Relative frequencies of Alnion incanae species in the oak-ash-elm (Fraxino pannonicaeUlmetum) and oak-hornbeam (ConvallarioCarpinetum) forests of Nyírség. (1) Relative frequency; (2) Relative frequency weighted with cover values.

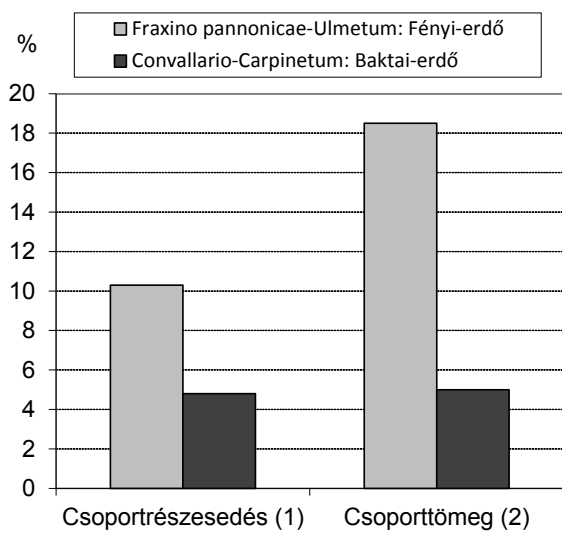

5. ábra. Alnion incanae elemek aránya a bátorligeti Fényi-erdő tölgy-kőris-szill ligeteiben ( $\mathrm{Fra}$ xino pannonicae-Ulmetum) és a baktalórántházi Baktai-erdő gyertyános-tölgyesében (Convallario-Carpinetum).

Fig. 5. Relative frequencies of Alnion incanae species in the oak-ash-elm (Fraxino pannonicaeUlmetum) forest of Fényi-erdő, Bátorliget and in the oak-hornbeam (Convallario-Carpinetum) forest of Baktai-erdő, Baktalórántháza. (1) Relative frequency; (2) Relative frequency weighted with cover values. 

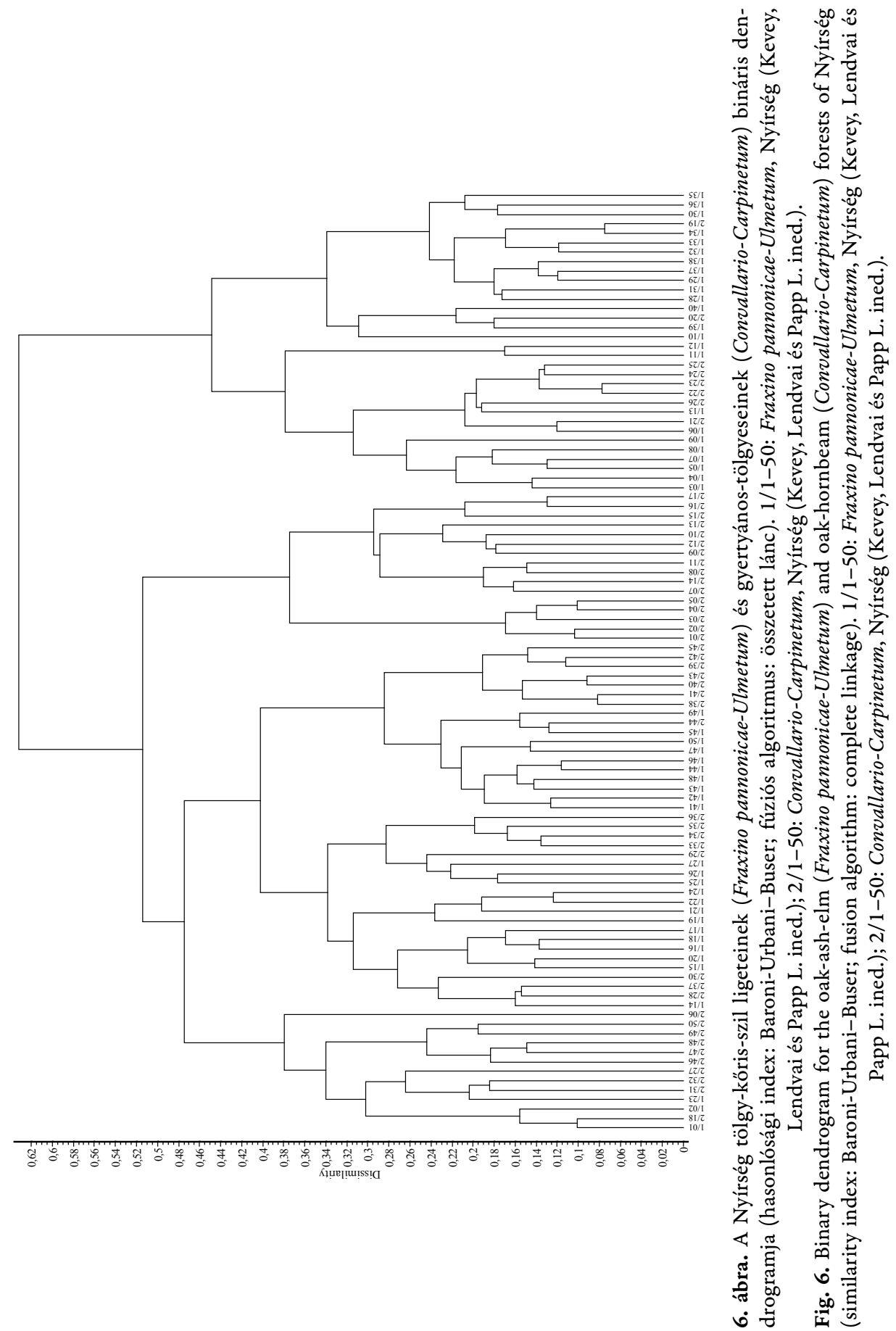
- K II: Festuca gigantea, Frangula alnus, Impatiens noli-tangere, Malus sylvestris, Populus alba, Rumex sanguineus, Ulmus laevis. - K I: Carex brizoides, Carex remota, Padus avium, Ribes rubrum, Viola elatior, Vitis sylvestris (E1. táblázat, elektronikus mellékletben). Arányuk alacsonyabb, mint a tölgy-kőris-szil ligetekben (Fraxino pannonicae-Ulmetum) (3. táblázat (elektronikus mellékletben), 3. ábra).

A karakterfajok arányát kiszámítottuk egy szükített - 40 felvételes - anyagon is. E célra a bátorligeti Fényi-erdőből, és a mérki Vadaskerti-erdőből, 10-10 gyertyános-tölgyes és ugyancsak 10-10 tölgy-kőris-szil ligeterdő felvételt használtunk fel elemzésre. Az eredményekből kitünik, hogy a két asszociáció között a karakterfajok arányában (pl. Fagetalia és Alnion incanae) lényegesen nagyobb a különbség (4-5. ábra), mint az 50-50 felvétel esetében (2-3. ábra).

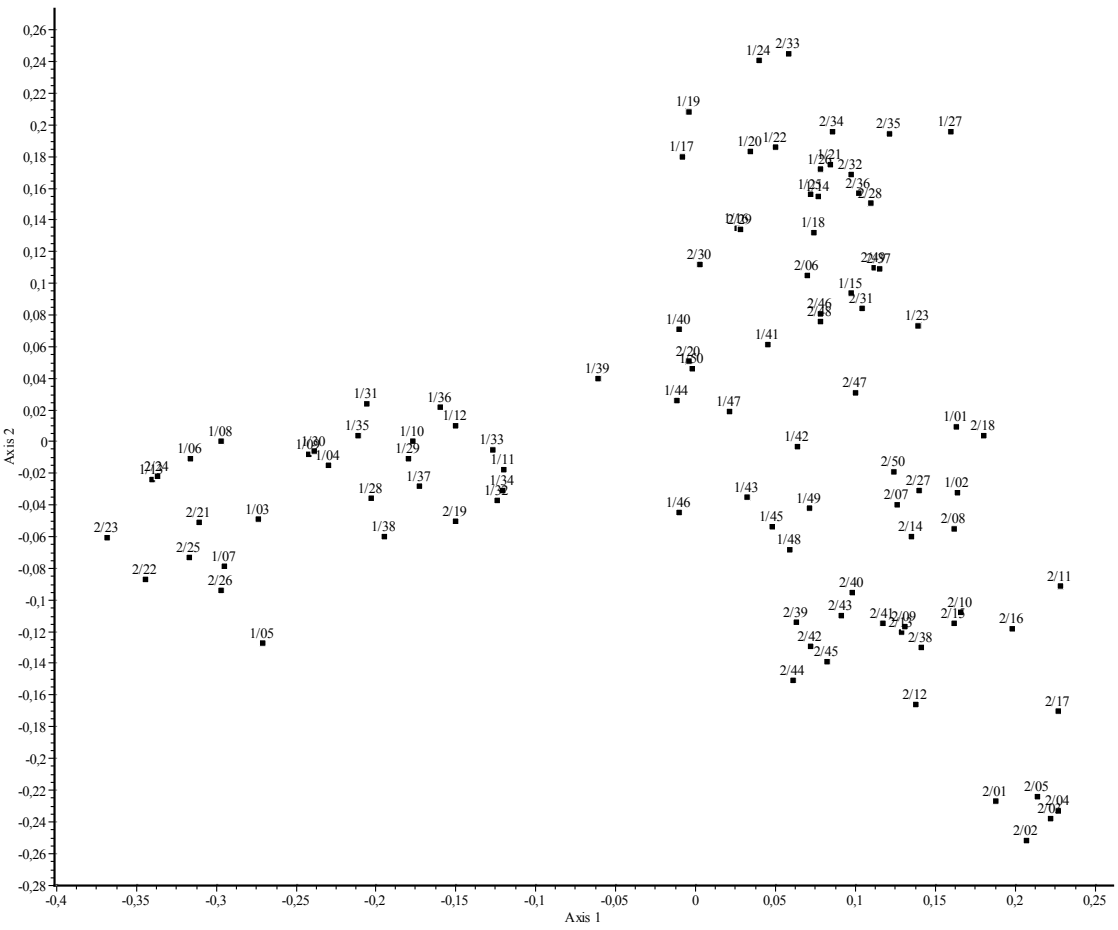

7. ábra. A Nyírség tölgy-kőris-szil ligeteinek (Fraxino pannonicae-Ulmetum) és gyertyános-tölgyeseinek (Convallario-Carpinetum) bináris ordinációs diagramja (hasonlósági index: Baroni-UrbaniBuser; fúziós algoritmus: főkoordináta-analízis). 1/1-50: Fraxino pannonicae-Ulmetum, Nyírség (Kevey, Lendvai és Papp L. ined.); 2/1-50: Convallario-Carpinetum, Nyírség (Kevey, Lendvai és Papp L. ined.).

Fig. 7. Binary ordination for the oak-ash-elm (Fraxino pannonicae-Ulmetum) and oak-hornbeam (Convallario-Carpinetum) forests of Nyírség (similarity index: Baroni-Urbani-Buser; algorithm: principal coordinates analysis). 


\section{Sokváltozós elemzések eredményei}

Ha bináris cluster-analízissel (6. ábra) és ordinációval (7. ábra) megvizsgáljuk a Nyírség tölgy-kőris-szil ligeteinek (Fraxino pannonicae-Ulmetum) és gyertyános-tölgyeseinek 50-50 felvételét, azt tapasztaljuk, hogy a két asszociáció egyértelműen nem választható szét, bár a dendrogramon és az ordinációs diagramon némi csoportosulások láthatók.

A sokváltozós elemzéseket egy szükebb anyagon is elvégeztük. E célra a bátorligeti Fényi-erdőből, és a mérki Vadaskerti-erdőből 10-10 gyertyános-tölgyes és ugyancsak 10-10 tölgy-kőris-szil ligeterdő felvételt használtunk fel elemzésre. Ennek eredményeként a dendrogramon (8. ábra) és az ordinációs diagramon (9.

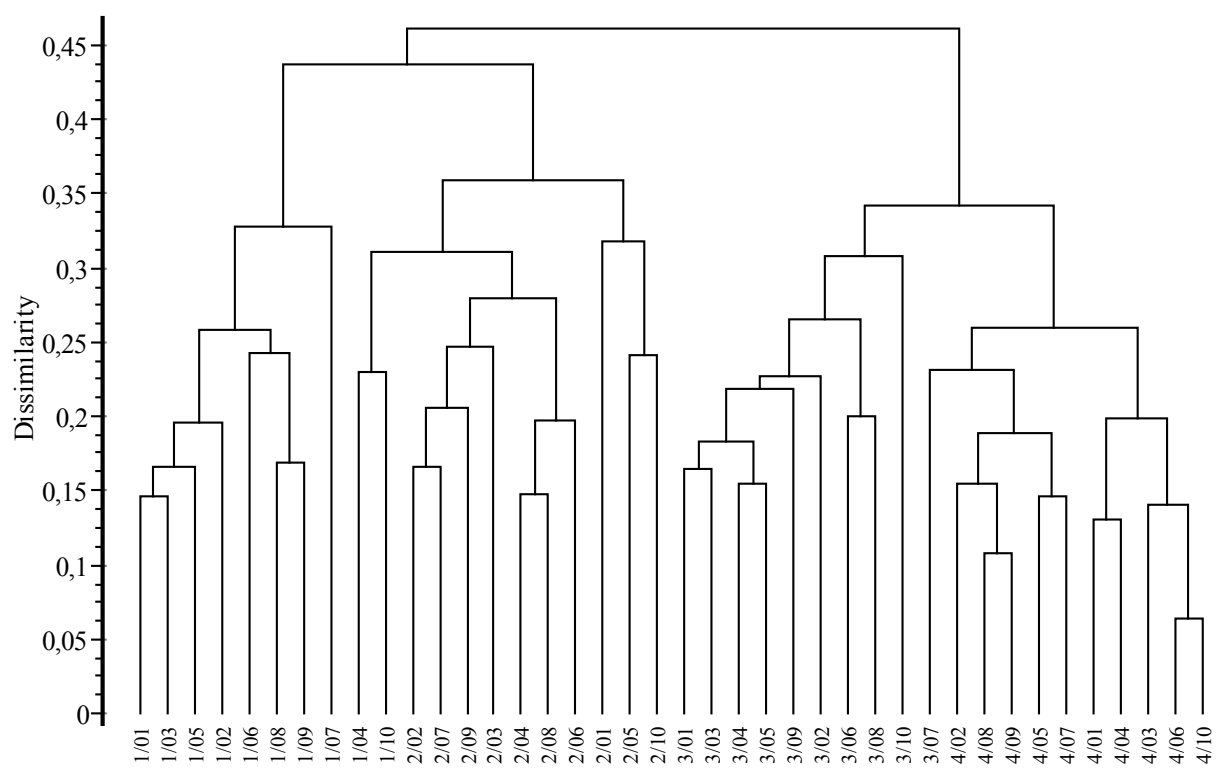

8. ábra. A bátorligeti Fényi-erdő és a mérki Vadaskerti-erdő tölgy-kőris-szil ligeteinek (Fraxino pannonicae-Ulmetum) és gyertyános-tölgyeseinek (Convallario-Carpinetum) bináris dendrogramja (hasonlósági index: Baroni-Urbani-Buser; fúziós algoritmus: összetett lánc). 1/1-10: Fraxino pannonicae-Ulmetum, Bátorliget Fényi-erdő (Kevey és Papp L. ined.); 2/1-10: Convallario-Carpinetum, Bátorliget Fényi-erdő (Kevey és Papp L. ined.); 3/1-10: Fraxino pannonicae-Ulmetum, Mérk Vadaskerti-erdő (Kevey, Lendvai és Papp L. ined.); 4/1-10: Convallario-Carpinetum, Mérk Vadaskerti-erdő (Kevey, Lendvai és Papp L. ined.).

Fig. 8. Binary dendrogram for oak-ash-elm (Fraxino pannonicae-Ulmetum) forest of Fényi-erdő (Bátorliget) and for the oak-hornbeam (Convallario-Carpinetum) forest of Vadaskerti-erdö (Mérk). (similarity index: Baroni-Urbani-Buser; fusion algorithm: complete linkage). 1/1-10: Fraxino pannonicae-Ulmetum, Bátorliget Fényi-erdő (Kevey és Papp L. ined.); 2/1-10: ConvallarioCarpinetum, Bátorliget Fényi-erdő (Kevey és Papp L. ined.); 3/1-10: Fraxino pannonicae-Ulmetum, Mérk Vadaskerti-erdő (Kevey, Lendvai és Papp L. ined.); 4/1-10: Convallario-Carpinetum, Mérk Vadaskerti-erdő (Kevey, Lendvai és Papp L. ined.). 
ábra) két-két fő csoportot kaptunk. Az egyikben a Fényi-erdő, a másikban pedig a Vadaskerti-erdő felvételei találhatók. Mindkét csoporton belül két-két alcsoport is megkülönböztethető, amelyek egyike tölgy-kőris-szil ligeterdő, a másik pedig gyertyános-tölgyes, bár ez az elkülönülés már nem tökéletes.

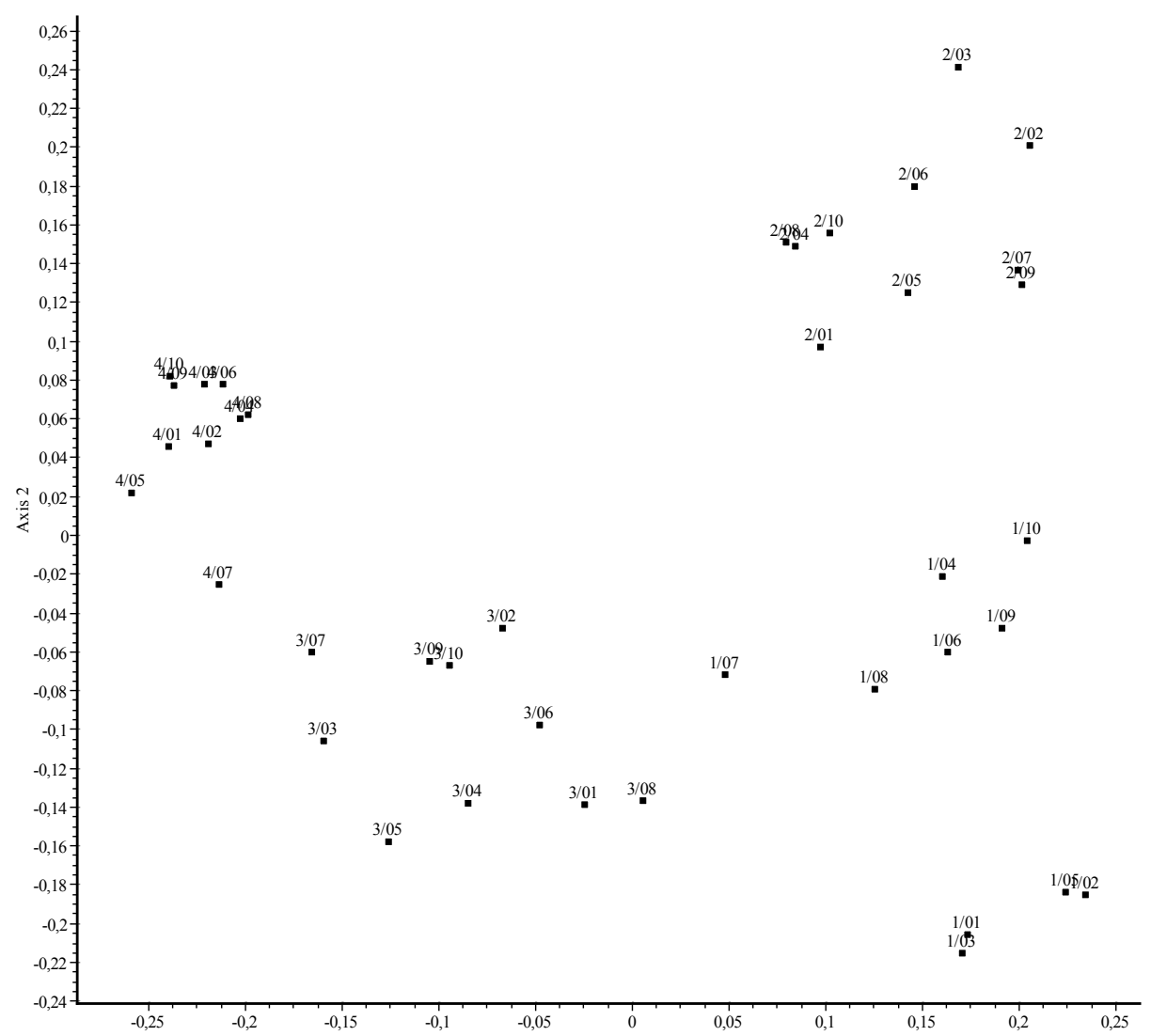

9. ábra. A bátorligeti Fényi-erdő és a mérki Vadaskerti-erdő tölgy-kőris-szil ligeteinek (Fraxino pannonicae-Ulmetum) és gyertyános-tölgyeseinek (Convallario-Carpinetum) bináris ordinációs diagramja (hasonlósági index: Baroni-Urbani-Buser; fúziós algoritmus: fókoordináta-analízis). 1/1-10: Fraxino pannonicae-Ulmetum, Bátorliget Fényi-erdő (Kevey és Papp L. ined.); 2/1-10: Convallario-Carpinetum, Bátorliget Fényi-erdő (Kevey és Papp L. ined.); 3/1-10: Fraxino pannonicae-Ulmetum, Mérk Vadaskerti-erdő (Kevey, Lendvai és Papp L. ined.); 4/1-10: Convallario-Carpinetum, Mérk Vadaskerti-erdő (Kevey, Lendvai és Papp L. ined.).

Fig. 9. Binary ordination for oak-ash-elm (Fraxino pannonicae-Ulmetum) forest of Fényi-erdő (Bátorliget) and for the oak-hornbeam (Convallario-Carpinetum) forest of Vadaskerti-erdő (Mérk). (similarity index: Baroni-Urbani-Buser; algorithm: principal coordinates analysis). 1/1-10: Fraxino pannonicae-Ulmetum, Bátorliget Fényi-erdő (Kevey és Papp L. ined.); 2/1-10: ConvallarioCarpinetum, Bátorliget Fényi-erdő (Kevey és Papp L. ined.); 3/1-10: Fraxino pannonicae-Ulmetum, Mérk Vadaskerti-erdő (Kevey, Lendvai és Papp L. ined.); 4/1-10: Convallario-Carpinetum, Mérk Vadaskerti-erdő (Kevey, Lendvai és Papp L. ined.). 
Végül e sokváltozós elemzéseket a bátorligeti Fényi-erdő tölgy-kőris-szil ligeteinek és a baktalórántházi Baktai-erdő gyertyános-tölgyeseinek összehasonlítása kapcsán is elvégeztük. A két asszociáció így már tökéletesen elkülönült (10-11. ábra).

\section{Megvitatás}

Mivel az állandósági osztályok fajszáma az akcidens (K I) elemektől a szubkonstans (K IV) és konstans (K V) elemekig szinte fokozatosan csökken (1. ábra), az asszociáció bizonyos fokú heterogén jellegére hívja fel a figyelmet. Ennek oka valószínűleg az erdők erős fragmentációja, izolációja, valamint a tájhaszná-

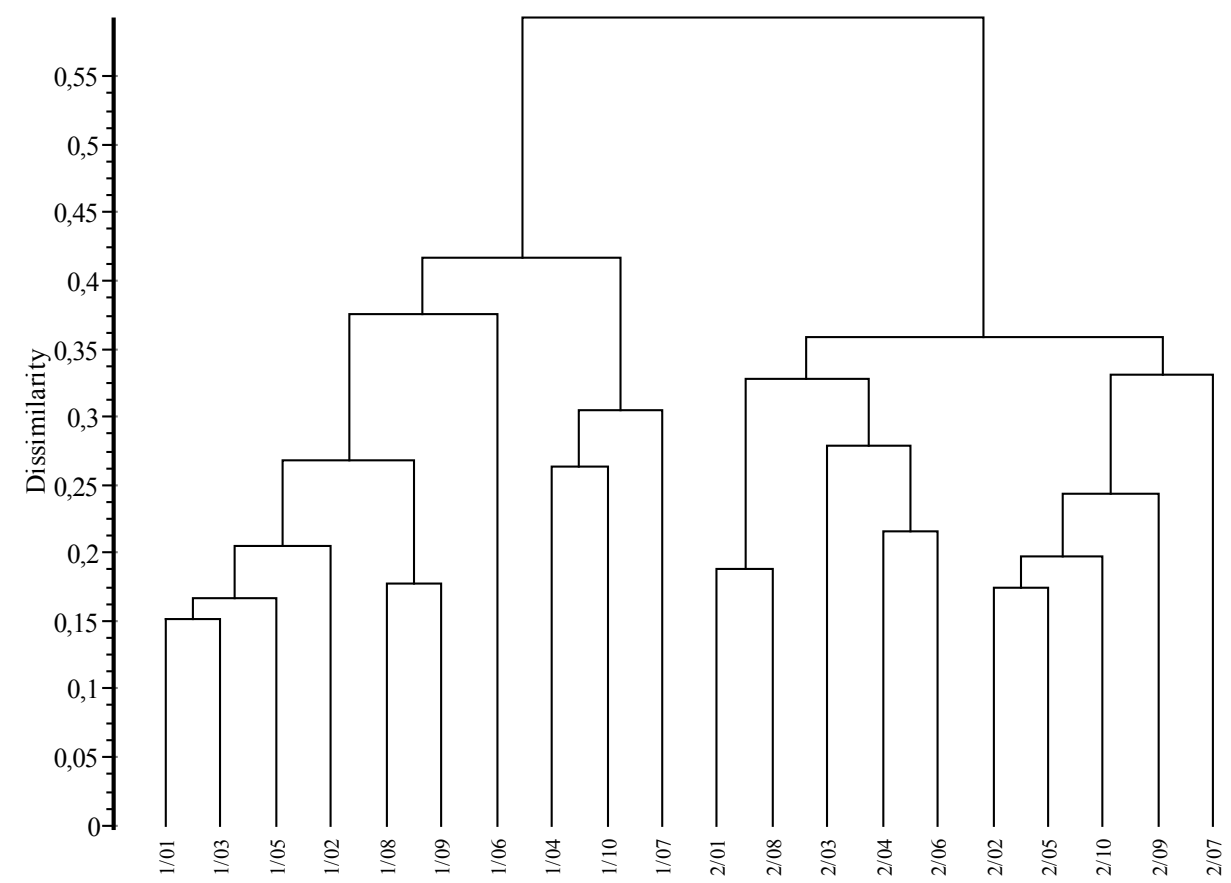

10. ábra. A bátorligeti Fényi-erdő tölgy-kőris-szil ligeteinek (Fraxino pannonicae-Ulmetum) és a baktalórántházi Baktai-erdő gyertyános-tölgyeseinek (Convallario-Carpinetum) bináris dendrogramja (hasonlósági index: Baroni-Urbani-Buser; fúziós algoritmus: összetett lánc). 1/1-10: Fraxino pannonicae-Ulmetum, Bátorliget Fényi-erdő (Kevey és Papp L. ined.); 2/1-10: ConvallarioCarpinetum, Baktalórántháza Baktai-erdő (Kevey ined.).

Fig. 10. Binary dendrogram for oak-ash-elm (Fraxino pannonicae-Ulmetum) forest of Fényi-erdő (Bátorliget) and for the oak-hornbeam (Convallario-Carpinetum) forest of Baktai-erdö (Baktalórántháza). (similarity index: Baroni-Urbani-Buser; fusion algorithm: complete linkage). 1/1-10: Fraxino pannonicae-Ulmetum, Bátorliget Fényi-erdő (Kevey és Papp L. ined.); 2/1-10: Convallario-Carpinetum, Baktalórántháza Baktai-erdő (Kevey ined.). 
lat, elsősorban a vízrendezések és az erdőgazdálkodás. E heterogén jelleg nehezíti meg a gyertyános-tölgyesek (Convallario-Carpinetum) és a tölgy-kőris-szil ligetek (Fraxino pannonicae-Ulmetum) cönológiai szétválasztását (1. táblázat, lásd később).

Az elemzési eredmények kapcsán szembetűnő, hogy a Nyírség gyertyánostölgyeseiben (Convallario-Carpinetum) alig több a Fagetalia elem, mint a tölgykőris-szil ligeterdőkben (Fraxino pannonicae-Ulmetum), s ez az arány elsősorban a csoportrészesedésnél jelentkezik (2. ábra). Ezen az alapon sokan felvetnék azt a kérdést, hogy a két vegetációs egységet érdemes-e külön asszociációként értelmezni? A Nyírségben azok az erdők, amelyekben ma még felismerhetők a gyertyánostölgyesek maradvány állományai, általában nagy távolságra vannak egymástól.

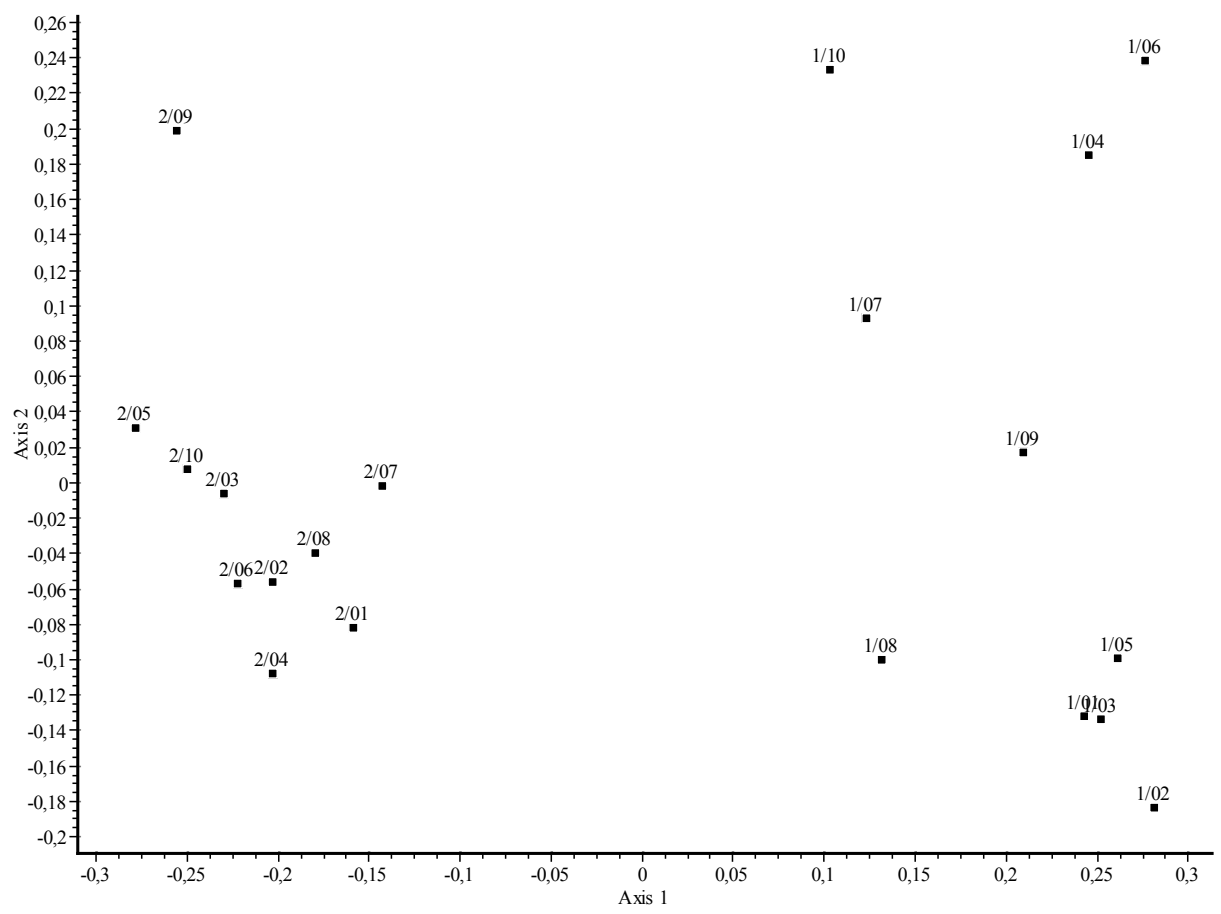

11. ábra. A bátorligeti Fényi-erdő tölgy-kőris-szil ligeteinek (Fraxino pannonicae-Ulmetum) és a baktalórántházi Baktai-erdő gyertyános-tölgyeseinek (Convallario-Carpinetum) bináris ordinációs diagramja (hasonlósági index: Baroni-Urbani-Buser; főkoordináta-analízis). 1/1-10: Fraxino pannonicae-Ulmetum, Bátorliget Fényi-erdő (Kevey és Papp L. ined.); 2/1-10: Convallario-Carpinetum, Baktalórántháza Baktai-erdő (Kevey ined.).

Fig. 11. Binary ordination diagram for oak-ash-elm (Fraxino pannonicae-Ulmetum) forest of Fényierdő (Bátorliget) and for the oak-hornbeam (Convallario-Carpinetum) forest of Baktai-erdő (Baktalórántháza). (similarity index: Baroni-Urbani-Buser; algorithm: principal coordinates analysis). 1/1-10: Fraxino pannonicae-Ulmetum, Bátorliget Fényi-erdő (Kevey és Papp L. ined.); 2/1-10: Convallario-Carpinetum, Baktalórántháza Baktai-erdő (Kevey ined.). 
Feltételezésünk szerint az asszociáció fragmentálódásával és izolációjával párhuzamosan az egyes elszigetelődött állományok faji összetétele a helyenként eltérő környezeti hatásoknak megfelelően változott: egyes fajok a lokális viszonyok között kiszorulhattak, mások viszont elterjedhettek. Így a Nyírség megmaradt gyertyános-tölgyes állományainak faji összetétele szinte erdőnként más és más lett.

Ezen eredményekből az a következtetés vonható le, hogy egy adott erdőben levő gyertyános-tölgyes állományok ugyanazon erdő tölgy-kőris-szil ligeteivel nagyobb hasonlóságot mutatnak, mint egy másik erdő gyertyános-tölgyesével és fordítva. Mindez az állományok fragmentációjával és izolációjával hozható összefüggésbe.

A sokváltozós elemzések (10. és 11. ábra) segítségével is sikerült élesen elkülöníteni a két erdőtársulást. Mindezekből az a következtetés vonható le, hogy hajdan, az emberi beavatkozások előtt a Nyírség egész területén hasonló módon különülhettek el a természetes tölgy-kőris-szil ligetek (Fraxino pannonicaeUlmetum) és a gyertyános-tölgyesek (Convallario-Carpinetum), mint jelen esetben a Fényi-erdő és a Baktai-erdő esetében láttuk. Az asszociáció helye a szüntaxonómiai rendszerben az alábbi módon vázolható:

Divisio: Querco-Fagea Jakucs 1967

Classis: Querco-Fagetea Br.-Bl. et Vlieger in Vlieger 1937 emend. Borhidi in Borhidi et Kevey 1996

Ordo: Fagetalia sylvaticae Pawłowski in Pawłowski et al. 1928

Alliance: Fagion sylvaticae Luquet 1926

Suballiance: Carpinenion betuli Issler 1931

Associatio: Convallario-Carpinetum Kevey 2008

\section{Természetvédelmi vonatkozások}

A Nyírség gyertyános-tölgyeseiben sok hegyvidéki, főleg Fagetalia növényfaj talál menedéket. Mint a tölgy-kőris-szil ligeteknél is láttuk, e szubmontán fajok (pl. Actaea spicata, Allium ursinum, Asarum europaeum, Cardamine bulbifera, Carex pilosa, Corydalis cava, Corydalis solida, Euphorbia amygdaloides, Galeobdolon luteum, Galium odoratum, Isopyrum thalictroides, Lathraea squamaria, Lathyrus vernus, Majanthemum bifolium, Mercurialis perennis, Milium effusum, Pulmonaria officinalis, Salvia glutinosa, Sanicula europaea, Stellaria holostea stb.) részben folyó hozta demontán adventív elemek, részben pedig a Bükk I. kor (i.e. 2500-tól i.e. 800-ig) maradványfajai (vö. Zólyomi 1936, 1952; JÁRAI-KoMLódI, M. 1966a, 1966b, 1968). Így e gyertyános-tölgyesek flóra- és vegetációtörténeti szempontból is jelentősek.

Az 50 cönológiai felvételből 15 védett növényfaj került elő: K II: Dryopteris carthusiana, Epipactis helleborine agg. (incl.: E. tallósii). - K I: Cephalanthera da- 
masonium, Cephalanthera longifolia, Lilium martagon, Listera ovata, Neottia nidusavis, Orchis militaris, Platanthera bifolia, Platanthera chlorantha, Scilla vindobonensis, Tamus communis, Thalictrum aquilegiifolium, Veratrum album, Vitis sylvestris.

Flóraszennyező hatást fejtenek ki egyes tájidegen növények: K II: Robinia pseudo-acacia. - K I: Acer negundo, Celtis occidentalis, Echinocystis lobata, Fraxinus pennsylvanica, Gleditsia triacanthos, Impatiens parviflora, Juglans nigra, Padus serotina, Parthenocissus inserta, Quercus rubra, Solidago gigantea, Stenactis annua. E fajok állandósága ugyan alacsony, de a valóságban ennél sokkal súlyosabb a helyzet, ugyanis a felvételi mintaterületek kiválasztásánál a degradáltabb állományokat nem mértük fel.

Mivel a homoki gyertyános-tölgyesek az Alföldön ma már igen ritkák, maradvány állományaik megőrzése, helyenkénti rekonstrukciója természetvédelmünk fontos feladata. Sajnos a Nyírségben ma már csak három erdőben található viszonylag nagyobb kiterjedésű gyertyános-tölgyes: Baktalórántháza Baktaierdő, Bátorliget Fényi-erdő, Mérk Vadaskerti-erdő. A többi helyeken csak kisebb (Debrecen Nagy-erdő: Medvesarok, Tiborszállás Ezüst-tábla), vagy csak egészen fragmentális (Nyíracsád Jónás-rész, Nyírvasvári Csírák, Terem Nagyfenék, Bátorliget Veres-folyás) állományok találhatók. Ezek az erdők mint parányi „oázisok" emelkednek ki a nyírségi akácosok kultúrsivatagából.

A Nyírség jelenkort megélő gyertyános-tölgyeseinek nagyobb része valamilyen védelemben részesült (2. táblázat). A nyíracsádi Jónás-rész a Hajdúsági Tájvédelmi Körzet részét képezi. Az országos jelentőségű természetvédelmi területekhez tartoznak a következők: Baktalórántháza Baktai-erdő; Bátorliget Fényierdő, Veres-folyás; Debrecen Nagy-erdő. Egyesek fokozott védelem alá is kerültek: Baktalórántháza Baktai-erdő; Bátorliget Fényi-erdő, Veres-folyás. Több erdő a Natura 2000 hálózat részét képezi: Baktalórántháza Baktai-erdő; Bátorliget Fényi-erdő, Veres-folyás; Debrecen Nagy-erdő; Nyíracsád Jónás-rész; Terem Nagyfenék. Végül semmilyen oltalomban sem részesült a Mérk melletti Vadaskert, a Nyírvasvári alatti Csonkás-erdő és a Tiborszállás melletti Ezüst-tábla erdeje. Véleményünk szerint e három erdőt is védetté kellene nyilvánítani, továbbá a mérki Vadas-kert és a Terem melletti Nagyfenék fokozott védelmet is érdemelne.

\section{Köszönetnyilvánítás}

Köszönetünk illeti azon kollégákat, akik segítették munkánkat: Aradi Csaba, Bartha Dénes, iff. Papp László.

\section{Rövidítések}

A1: felső lombkoronaszint; A2: alsó lombkoronaszint; Agi: Alnenion glutinosaeincanae; Ai: Alnion incanae; APa: Abieti-Piceea; AQ: Aceri tatarici-Quercion; Ar: 
1. táblázat. Differenciális fajok. U: Fraxino pannonicae-Ulmetum, Nyírség (Kevey, Lendvai és Papp ined.: 50 felv.); Cp: Convallario-Carpinetum, Nyírség (Kevey, Lendvai és Papp ined.: 50 felv.).

Table 1. Differential species. U: Fraxino pannonicae-Ulmetum, Nyírség (Kevey, Lendvai, Papp ined.: 50 relevés); Cp: Convallario-Carpinetum, Nyírség (Kevey, Lendvai, Papp ined.: 50 relevés); (1) Number of differential species.

\begin{tabular}{lcc}
\hline & U & Cp \\
\hline Ulmus laevis & V & II \\
Ajuga reptans & V & III \\
Cornus sanguinea & V & III \\
Corylus avellana & V & III \\
Rubus caesius & V & III \\
Carex remota & IV & I \\
Pulmonaria officinalis & IV & II \\
Torilis japonica & IV & II \\
Aegopodium podagraria & III & I \\
Allium ursinum & III & I \\
Anemone ranunculoides & III & I \\
Lysimachia nummularia & III & I \\
Carpinus betulus & III & V \\
Cerasus avium & II & IV \\
Fallopia dumetorum & II & IV \\
Galeopsis pubescens & II & IV \\
Differenciális fajok száma (1) & I2 & 4 \\
\hline
\end{tabular}

2. táblázat. A Nyírség gyertyános-tölgyeseinek védettsége.

Table 2. Nature conservation status for the oak-hornbeam forests of Nyírség. Part of the Hajdúság Landscape Protection Area; Area protected at the national level; Strictly protected; Natura 2000 site.

\begin{tabular}{llcccc}
\hline Település & Dülönév & $\begin{array}{c}\text { Hajdúsági } \\
\text { TK része }\end{array}$ & $\begin{array}{c}\text { Országos jelen- } \\
\text { tőségü TT }\end{array}$ & $\begin{array}{c}\text { Fokozot- } \\
\text { tan védett }\end{array}$ & $\begin{array}{c}\text { Natura 2000- } \\
\text { es terület }\end{array}$ \\
\hline Baktalórántháza & Baktai-erdő & - & $\times$ & $\times$ & $\times$ \\
Bátorliget & Fényi-erdő & - & $\times$ & $\times$ & $\times$ \\
Bátorliget & Veres-folyás & - & $\times$ & $\times$ & $\times$ \\
Debrecen & Nagy-erdő & - & $\times$ & - & $\times$ \\
Mérk & Vadas-kert & - & - & - & - \\
Nyíracsád & Jónás-rész & $\times$ & - & - & $\times$ \\
Nyírvasvári & Csonkás-erdő & - & - & - & - \\
Terem & Nagyfenék & - & - & - & $\times$ \\
Tiborszállás & Ezüst-tábla & - & - & - & - \\
\hline
\end{tabular}


Artemisietea; Ara: Arrhenatheretea; Arn: Arrhenatherion elatioris; Ate: Alnetea glutinosae; B1: cserjeszint; B2: újulat; Ber: Berberidion; Bia: Bidentetea; C: gyepszint; Cal: Calystegion sepium; Che: Chenopodietea; ChS: Chenopodio-Scleranthea; Cp: Carpinenion betuli; Des: Deschampsion caespitosae; Epa: Epilobietea angustifolii; Epn: Epilobion angustifolii; EuF: Eu-Fagenion; F : Fagetalia sylvaticae; FBt: Festuco-Brometea; FiC: Filipendulo-Cirsion oleracei; FPi: Festuco-Puccinellietalia; Fru: Festucion rupicolae; Fvl: Festucetalia valesiacae; GA: Galio-Alliarion; GU: Galio-Urticetea; incl.: inclusive (beleértve); ined.: ineditum (kiadatlan közlés); Mag: Magnocaricetalia; Moa: Molinietalia coeruleae; MoA: Molinio-Arrhenatherea; MoJ: Molinio-Juncetea; NC: Nardo-Callunetea; OCn: Orno-Cotinion; Pla: Plantaginetea; Pna: Populenion nigro-albae; PP: PulsatilloPinetea; PQ: Pino-Quercetalia; Prf: Prunion fruticosae; Pru: Prunetalia spinosae; Pte: Phragmitetea; Qc: Quercetalia cerridis; Qfa: Quercion farnetto; QFt: Querco-Fagetea; Qpp: Quercetea pubescentis-petraeae; Qr: Quercetalia roboris; Qrp: Quercion roboripetraeae; S: summa (összeg); Sal: Salicion albae; Sea: Secalietea; s.l.: sensu lato (tágabb értelemben); Spu: Salicetea purpureae; TA: Tilio platyphyllae-Acerenion pseudoplatani; Ulm: Ulmenion; US: Urtico-Sambucetea; VP: Vaccinio-Piceetea.

\section{Irodalomjegyzék}

BeCKIng R. W. 1957: The Zürich-Montpellier School of phytosociology. Botanical Review 23: 411-488. http://doi.org/10.1007/bf02872328

BorHidi A. 1961: Klimadiagramme und klimazonale Karte Ungarns. Annales Universitatis Scientiarum Budapestinensis, Sectio Biologica 4: 21-250.

BoRHIDi A. 1993: A magyar flóra szociális magatartás típusai, természetességi és relatív ökológiai értékszámai. Janus Pannonius Tudományegyetem, Pécs, 95 pp.

BoRHIDI A. 1995: Social behaviour types, the naturalness and relative ecological indicator values of the higher plants in the Hungarian flora. Acta Botanica Academiae Scientiarum Hungaricae 39: 97-181.

Borhidi A., Kevey B. 1996: An annotated checklist of the Hungarian plant communities II. In: Borhidi A. (ed.): Critical revision of the Hungarian plant communities. Janus Pannonius University, Pécs, pp. 95-138.

Borhidi A., Kevey B., Lendvai G. 2012: Plant communities of Hungary. Akadémiai Kiadó, Budapest, $544 \mathrm{pp}$.

Braun-Blanduet J. 1964: Pflanzensoziologie (ed. 3.). Springer Verlag, Wien-New York, 865 pp.

Horváth F., Dobolyi Z. K., Morschhauser T., Lökös L., Karas L., Szerdahelyi T. 1995: Flóra adatbázis 1.2. MTA Ökológiai és Botanikai Kutatóintézete, Vácrátót, 267 pp.

IsSLER E. 1931: Les associations silvatiques haut-rhinoises. Bulletin de la Société Botanique de France 78, Paris.

JAKUCS P. 1967: Gedanken zur höheren Systematik der europäischen Laubwälder. Contribuții Botanice, Cluj 1967: 159-166.

JÁRAI-KomLóDi M. 1966a: Palinológiai vizsgálatok a Magyar Alföldön a Würm glaciális és a holocén klíma- és vegetációtörténetére vonatkozóan. Kandidátusi értekezés (Kézirat).

JÁRAI-KomLóDi M. 1966b: Adatok az Alföld negyedkori klíma- és vegetációtörténetéhez I. Botanikai Közlemények 53: 191-201.

JÁRAI-KomLóDi M. 1968: The late glacial and Holocene flora of the Hungarian Great Plain. Annales Universitatis Scientiarum Budapestinensis, Sectio Biologica 9-10: 199-225. 
KEVEY B. 2008: Magyarország erdőtársulásai (Forest associations of Hungary). Die Wälder von Ungarn. Tilia 14: 1-488. + CD-adatbázis (230 táblázat + 244 ábra).

Kevey B., HirmanN A. 2002: „NS” számítógépes cönológiai programcsomag. In: Horváth A. (szerk.): Aktuális flóra- és vegetációkutatások a Kárpát-medencében V. Pécs, 2002. március 8-10. (Összefoglalók), Pécsi Tudományegyetem Növénytani Tanszék, Duna-Dráva Nemzeti Park Igazgatósága, Baranya Megyei Múzeumok Igazgatósága, Kosbor Természetvédelmi Egyesület, Pécs, pp. 74.

Kevey B., Papp L., LendVai G. 2017: A Nyírség tölgy-kőris-szil ligetei (Fraxino pannonicae-Ulmetum Soó in AszóD 1935 corr. Soó 1963). Kitaibelia 22 (in press).

KIRÁLY G. (szerk.) 2009: Új magyar füvészkönyv. Magyarország hajtásos növényei. Határozókulcsok. Aggteleki Nemzeti Park Igazgatóság, Jósvafö, 616 pp.

LuQUET A. 1926: Essai sur la geographie botanique de l'Auvergne. Les associations végétales du Massif des Monts-Dores. Geographie Botanique de l'Auvergne. Les Presses Universitaires de France, Paris, pp. 1-263.

Mucina L., Grabherr G., Wallnöfer S. 1993: Die Pflanzengesellschaften Österreichs III. Wälder und Gebüsche. Gustav Fischer, Jena - Stuttgart - New York, 353 pp.

Oberdorfer E. 1992: Süddeutsche Pflanzengesellschaften IV. A. Textband. Gustav Fischer Verlag, Jena - Stuttgart. New York, $282 \mathrm{pp}$.

Papp M., ANTAL M., DÁvid J., TöröK T. 1986: A Fényi erdő vegetációja. Botanikai Közlemények 73(1-2): 43-48.

PawŁows k B., SokoŁows ki M., Wallisch K. 1928: Die Pflanzenassoziationen des Tatra-Gebirges VII. Die Pflanzenassoziationen und die Flora des Morskie Oko-Tales. Bulletin International de l'Academie Polonaise des Sciences et des Lettres, Classe des Sciences Mathématiques et Naturelles; Série B: Sciences Naturelles, Cracovie, Suppl. 1927: 205-272.

PoDAni J. 2001: Syn-Tax 2000. Computer programs for data analysis in ecology and systematics. Scientia, Budapest, 53 pp.

Soó R. 1937: A Nyírség erdői és erdőtípusai. Erdészeti Kísérletek 39: 337-380.

Soó R. 1943: A nyírségi erdők a növényszövetkezetek rendszerében. Acta Geobotanica Hungarica 5: $315-352$.

Soó R. 1953: A növénytakaró. In: SzÉKessy V. (szerk.): Bátorliget élővilága. Akadémiai Kiadó, Budapest, pp. 45-57.

Soó R. 1960: Magyarország új florisztikai-növényföldrajzi felosztása. Magyar Tudományos Akadémia Biológiai Csoportjának Közleményei 4: 43-70.

Soó R. 1964, 1966, 1968, 1970, 1973, 1980: A magyar flóra és vegetáció rendszertani-növényföldrajzi kézikönyve I-VI. Akadémiai Kiadó, Budapest.

Vlieger J. 1937: Aperçu sur les unités phytosociologiques supérieures des Pays-Bas. Nederlandsh Kruidkundig Archief 47: 335.

Zólyomi B. 1936: Tízezer év története virágporszemekben. Természettudományi Közlöny 68: 504-516.

Zólyomi B. 1952: Magyarország növénytakarójának fejlődéstörténete az utolsó jégkorszaktól. Magyar Tudományos Akadémia Biológiai Osztályának Közleményei 1: 491-530.

Elektronikus melléklet: E1-E3. táblázatok

Electronic supplement: Tables E1-E3.

E1. táblázat. Convallario-Carpinetum, Nyírség

Table E1. Convallario-Carpinetum, Nyírség 
E2. táblázat. Felvételi adatok az 1. táblázathoz.

Table E2. Relevés data for Table 1.

E3. táblázat. Karakterfajok aránya

Table E3. Relative frequencies of character species.

\title{
The oak-hornbeam forests of Nyírség, Hungary
}

\author{
B. KEVEY ${ }^{1}$, L. PAPP ${ }^{2}$ and G. LENDVAI ${ }^{3}$ \\ ${ }^{1}$ University of Pécs, Department of Ecology, \\ Ifjúság útja 6, H-7624 Pécs; keveyb@ttk.pte.hu \\ ${ }^{2}$ University of Debrecen, Botanical Garden, \\ Egyetem tér 1, H-4032 Debrecen; papp.laszlo@gf.unideb.hu \\ ${ }^{3}$ Ady E. u. 162, H-7000 Sárbogárd; gaborlendvai@hotmail.com
}

Accepted: 18 March 2017

Key words: cluster analysis, Hungarian Plain, nature reserve, ordination, phytosociology.

This paper presents the main findings of the phytosociological analyses of oak-hornbeam forests growing in the Nyírség, NE Hungary. These climatically extrazonal forests grow in habitats with moderately moist soil owing to the relatively high groundwater table, which maintains rather mesic conditions. They are particularly rich in Fagetalia elements (Actaea spicata, Allium ursinum, Anemone ranunculoides, Arum orientale, Asarum europaeum, Athyrium filix-femina, Cardamine bulbifera, Carex pilosa, Carpinus betulus, Cerasus avium, Corydalis cava, Corydalis solida, Dryopteris filix-mas, Epipactis helleborine agg., Euphorbia amygdaloides, Galeobdolon luteum, Galium odoratum, Hedera helix, Isopyrum thalictroides, Lathraea squamaria, Lathyrus vernus, Lilium martagon, Majanthemum bifolium, Mercurialis perennis, Milium effusum, Polygonatum multiflorum, Pulmonaria officinalis, Ranunculus cassubicus, Salvia glutinosa, Sanicula europaea, Scilla vindobonensis, Stachys sylvatica, Stellaria holostea, Ulmus glabra, Vinca minor, etc.) typical in the submontane regions of this part of Europe. These species are usually rare in other parts of the Great Hungarian Plain, and occur mostly in the eastern part of the Nyírség. It is possible that they are remnants of the vegetation dominating the region during the Beech phase (2500-800 BC) of the Holocene. These forests are highly similar to the oak-ash-elm forests (Fraxino pannonicae-Ulmetum), which also grow within the region. 